\title{
TURBULENT HISTORY, TROUBLESOME HERITAGE: POLITICAL CHANGE, SOCIAL TRANSFORMATION, AND THE POSSIBILITIES OF REVIVAL IN THE “OLD JEWISH QUARTER” OF BUDAPEST
}

\author{
ERIKA SZÍVÓS
}

\author{
Eötvös Loránd University \\ E-mail: szivos.erika@btk.elte.hu
}

\begin{abstract}
This article explores the history of Belsö-Erzsébetváros, the Inner $7^{\text {th }}$ District of Budapest, an urban area regarded as a historic Jewish quarter in today's discourse. The historical summary focuses on societal transformations caused by political changes and historical tragedies during the $20^{\text {th }}$ century. One explicit goal is to show in which ways the Inner $7^{\text {th }}$ District of Budapest is unique among similar historic districts of other Central European cities: in Central European comparison, a large proportion of its population - just like the Jewish population of Budapest in general - survived the Holocaust. Therefore Jewish heritage has been experienced differently there than elsewhere in cities of the region.

After briefly introducing the historical evolution of the Inner $7^{\text {th }}$ District before World War II, the article portrays local society, and explores the social relations that characterized this area until the last years of the World War II. Patterns of ethnic and confessional intermixing will be interpreted as defining characteristics of the district in the interwar period. Then the author will show the way wartime events and political measures disrupted the social fabric of the neighborhood, and transformed the local population dramatically by the spring of 1945. At the same time, patterns of survival will be also emphasized. After discussing the impact of World War II and the Holocaust, the article will highlight the post-1945 shifts in local society, exploring the impact of migration as well as the connection between societal transformation and the area's physical decay in the Communist period. Finally, the author will briefly touch upon the past 25 years, discussing the possibilities of revival in the area, pointing out the role of Jewish heritage in the recent rediscovery of the neighborhood.
\end{abstract}

Keywords: urban society, Jewish history, Holocaust, World War II, migration, heritage, urban renewal, Budapest, Hungary

\section{Introduction}

The revitalization of centrally located historic districts is often linked to the revival of an area's particular heritage. In certain Central European cities, the revival of former "Jewish quarters" have been a characteristic process of the past twenty years. The rediscovery of local Jewish heritage has become an important 
motif in the regeneration of urban areas such as Josefov in Prague, Kazimierz in Cracow, the Scheunenviertel in Berlin, or the Leopoldstadt in Vienna (Gruber, 2002; Gruber, 2009; all the articles in Murzyn-Kupisz and Purchla eds., 2009; Murzyn, 2006; Kalmár and Stelzer, 2000; Szívós, 2012a) This article is going to focus on one of these urban quarters: namely the Inner $7^{\text {th }}$ District of Budapest, an area that is often regarded as the "Old Jewish Quarter" of the city these days.

The $20^{\text {th }}$-century evolution of this quarter - named Belsö-Erzsébetváros (Inner Elisabethtown) in Hungarian - is in many ways similar to those of its Central European counterparts, and in some respects its early $21^{\text {th }}$-century revival can be compared to the varieties of revival that have been taking place in the Scheunenviertel, in Josefov, in Leopoldstadt, or in Kazimierz. At the same time, the dissimilarities between the Inner $7^{\text {th }}$ District of Budapest and the historic Jewish quarters of other Central European metropolises must be immediately apparent.

There are several reasons to treat Belsö-Erzsébetváros as an untypical case. First of all, uniquely among historic "Jewish districts" of Central European cities, a substantial part of its Jewish population survived the Holocaust, and that surviving population remained an important component in the area's social makeup during the post-World-War-II decades and even beyond, in spite of the strong tendencies of Jewish out-migration from the area (Ladányi, 2013, 220222.). For specific historical reasons, the overall number of Holocaust survivors and returnees in Budapest was in general the highest in the region compared to all other Central European cities (Stark, 1995, 53 and 64, compared to e. g. Murzyn, 2006, 118-120; Pař́k, 2009, 199; or Kalmár and Stalzer, 2000, 14) The consequence of that has been the continuous presence of a relatively large Jewish population in the Hungarian capital city up to this very day (Kovács ed., 2002). Whether Jewish should be understood in terms of religion, origin, or identity may vary from period to period, but in any case, for the above reasons, the Inner $7^{\text {th }}$ District of Budapest as a place of memory and a place of identification functions differently today than similar districts do elsewhere in Central Europe - i. e. districts from which Jewish residents practically disappeared after World War II (Gruber, 2002, 7).

Secondly, as far as urban regeneration in the late 1990s and early 2000s is concerned, the Inner $7^{\text {th }}$ District of Budapest is a special case because of its prolonged stagnation and its belated - still questionable - gentrification. Compared to Josefov, Berlin Mitte, Leopoldstadt, or Kazimierz, urban renewal in the Inner $7^{\text {th }}$ District of Budapest has been halted by several factors since the political transition of 1990, and has remained incomplete up to this day (Csanádi, Csizmady and Olt, 2012, 51-124).

My intention in this article is to highlight the specific historical factors that have shaped the characteristics of the Inner $7^{\text {th }}$ District of Budapest during the past century. In order to draw the historical context in which today's controversial 
urban renewal is taking place, I will portray processes of social transformation that affected the area during the $20^{\text {th }}$ and early $21^{\text {st }}$ century, relying on the already existing, extensive body of literature as well as on my own research.

\section{The Evolution of the “Old Jewish Quarter” from the Beginnings to Word War II}

The history of the district began in the $18^{\text {th }}$ century. The area evolved as one of the earliest suburbs of $18^{\text {th }}$-century Pest. At that time Buda and Pest were two separate towns, with privileges established by royal charters. The new suburb of Pest was named Terézváros (Theresatown) after the Habsburg Empress Maria Theresa, and was located outside the city walls. Its first inhabitants were not Jews but Christian artisans and tradespeople of modest means, who had little chance to acquire burgher's rights in the city of Pest (Keresztély, 2009, 166) and who therefore settled down in the cheaper and at that time wholly unregulated outskirts.

Soon, however, the area began to attract Jewish migrants as well. Up until the end of the $18^{\text {th }}$ century, Jews had been mostly banned from royal chartered towns in Hungary, similarly to other countries of the region. In 1781, Emperor Joseph II issued the so-called Decree of Tolerance, which allowed Jews in Hungary to settle down in chartered cities, although with limitations (Frojimovics et al., 1999, 69).

From that time on, the inner part of Terézváros developed into an area of concentrated Jewish settlement, and functioned as the first harbor for newcomers who wished to establish themselves in the city. Certain spots, such as the Orczy House complex with its multiple courtyards, played a particularly important role in providing new arrivals with a supportive environment and all the essential institutions of Jewish life. (Frojimovics et al., 1999, 67-74). From the 1830s on, due to the removal of legal barriers, the wealthiest Jews tended to choose their residence in the inner city of Pest, primarily in the quarter called Lipótváros (Leopoldtown), while the less affluent majority tended to remain in Terézváros (Keresztély, 2009, 166). The gradual departure of the Jewish elite notwithstanding, over $70 \%$ of Pest Jews lived in Terézváros in the 1840s, and that proportion remained almost the same as late as 1870 (Bácskai, 1995, 9 and Zeke, 1990, 170). The Inner Terézváros (today's Inner $7^{\text {th }}$ and partly the Inner $6^{\text {th }}$ District) remained the real hub of Jewish religious and community life. From the early $19^{\text {th }}$ century onwards, the area has been home to synagogues, prayer houses as well as many other Jewish institutions, and continued to have a high percentage of Jewish residents until World War II.

In spite of its strongly Jewish character, however, the Inner Terézváros was never homogeneously Jewish: Christian churches and Gentile residents were just 
as strongly part of the local milieu. The neighborhood was home to various ethnic groups and languages, including Hungarian, German, Yiddish, and Romanian - with transitional dialects such as "jüdisch deutsch" and bilingualism or the knowledge of more than two languages being fairly common until the end of the 19th century. (Fenyves, 2010, 180-184). As opposed to some other Central European Jewish districts, e. g. Josefov in Prague, the inner part of Terézváros never officially functioned as a ghetto - i.e. an area of compulsory residence for Jews - during its $18^{\text {th }}$-and early $19^{\text {th }}$-century history, although in the figurative sense it was sometimes called "the ghetto" in mémoires and literary narratives. Tamás Kóbor, a turn-of the-century Jewish writer who grew up in the area in the 1860s and 1870s, published an autobiographical novel titled "Out of the Ghetto" in 1930, creating one of the seminal narrative sources on old Terézváros for posterity (Kóbor, 2007 [1930]).

The neighborhood certainly had the reputation of a Jewish quarter in the late $19^{\text {th }}$ and early $20^{\text {th }}$ century, but that popular image was in fact limited to only a few streets where Jews represented an absolute majority. In the national census of 1900 , the $7^{\text {th }}$ District was broken down into smaller units, represented on a map attached to the Budapest summary of that census. Within a certain area, 51 to $80 \%$ of the population was Jewish in 1900 in terms of religious denomination; that area was bordered roughly by today’s Károly Boulevard, Andrássy Avenue, Csányi Street and Dob Street (see the map titled „Az izraeliták eloszlása” [Distribution of Israelites] in Körösi and Thirring 1905, 56-57).

Apart from that narrow area, the presence of Jews was strongly counterbalanced by Christian denominations. On the district level, the proportion of denominationally Jewish residents within the $7^{\text {th }}$ District was 35.8\% in 1900 (compared to the Budapest figure of 23.6\%). Their proportion in the $7^{\text {th }}$ District fluctuated between 30 to nearly 40\% between 1910 and 1935, declining slightly toward the end of the interwar period (Table 1, based on Thirring 1935, 43, and Budapest Székesföváros Statisztikai Évkönyve 1941., KSH, Bp. 1941.)

Table 1. The proportion of Jewish versus Christian denominations in the whole $7^{\text {th }}$ District, 1900-1941

\begin{tabular}{lccccc}
\hline & 1900 & 1910 & 1920 & 1930 & 1941 \\
\hline Jewish & 35.8 & 38.5 & 39.1 & 36.6 & 28.5 \\
Christian denominations & 64.2 & 62.5 & 60.9 & 63.7 & 71.5 \\
\hline
\end{tabular}

After Budapest as a national capital had been officially created in 1873 by the unification of formerly independent towns Pest, Buda, and Óbuda, the position of Terézváros was finalized in the new system of city administration. It was split 
into two administrative units, namely the $6^{\text {th }}$ and the $7^{\text {th }}$ Districts; the $7^{\text {th }}$ District then adopted the name Erzsébetváros (Elizabethtown) in 1882, in honor of Empress Elizabeth, spouse of Emperor Franz Joseph I, and the use of the name "Terézváros" was from then on restricted to the $6^{\text {th }}$ District only (see Figure 1 ). The name mostly used throughout this article for the area (Inner $7^{\text {th }}$ District) thus dates back to the administrative reorganization of the early 1870 s.

After 1873, Budapest was consciously developed into a grandiose European metropolis. As part of the large-scale urban construction projects carried out at that time, the major boulevards and avenues bordering on the Inner $7^{\text {th }}$ District acquired their architectural character between 1870 and 1896.

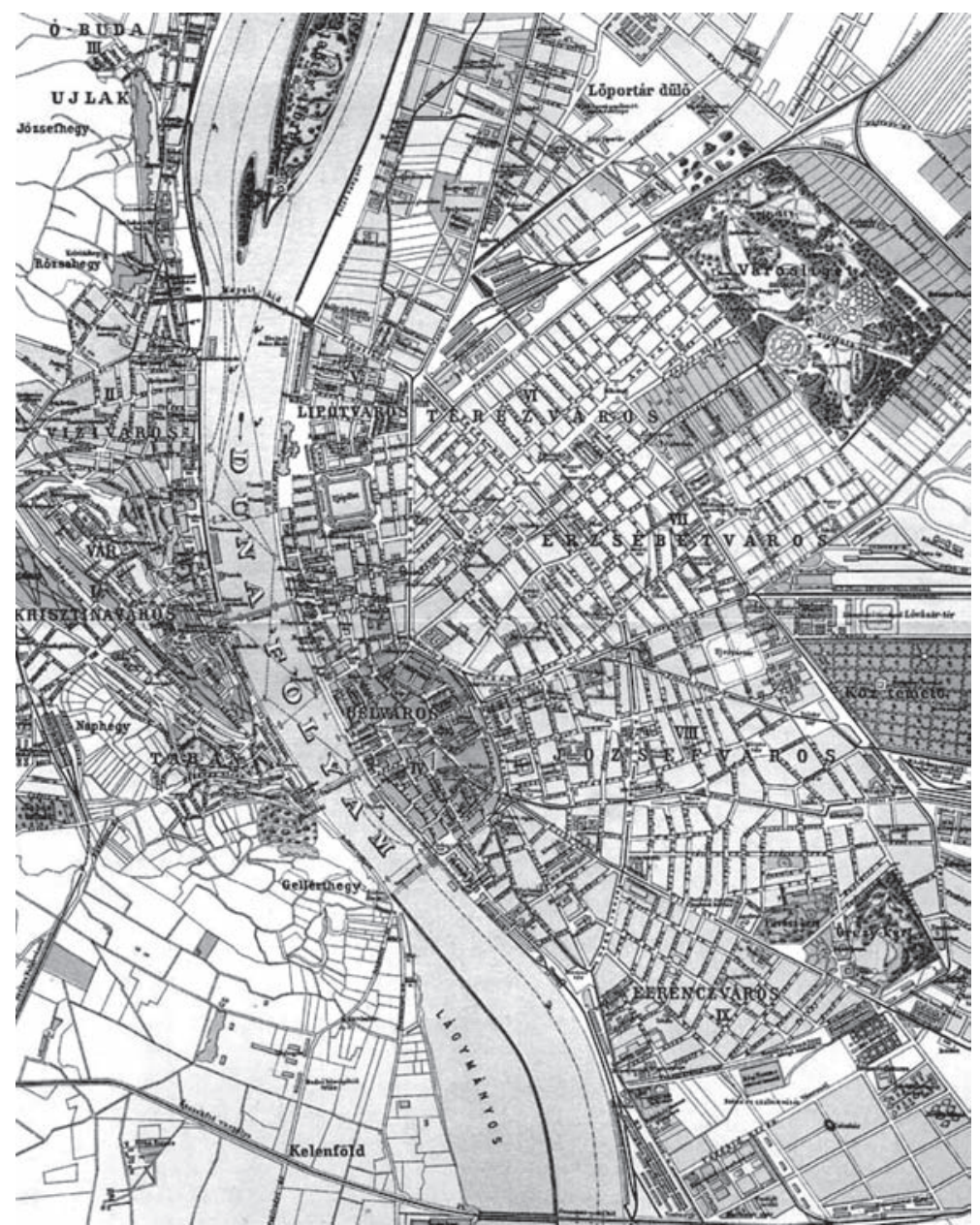

Figure 1. Map of Budapest in the early $20^{\text {th }}$ century, with Erzsébetváros, the $7^{\text {th }}$ District (VII) east of the center 
The Inner $7^{\text {th }}$ District thus developed a certain dual character by the end of the $19^{\text {th }}$ century. The outer main streets, such as Andrássy Avenue, Erzsébet Boulevard, and Kerepesi (today Rákóczi) Road were prestigious, fashionable, and upscale, with cafés, theatres, and, after 1900, more and more cinemas. (Koltai and Rácz, 2011, 91-100; Fabó 1997). Several editorial offices and publishing houses were located on the main streets as well. The inner side streets, on the other hand, were busy but more humble, with little stores, workshops, smaller factories, and printing presses, many of which had Jewish owners and employees. In addition to small trade, lowbrow entertainment facilities like cafés chantants (Sängerei in German, zengeráj in Hungarian), later cabarets and orfeums were lining the broader inner streets of the quarter, concentrated especially in the neighborhood's traditional thoroughfare Király Street and in Nagymező Street (Konrád, 2013; Perczel, 2014, 62-71; Molnár Gál, 2005). The same duality - namely the metropolitan bustle of the main avenues versus the more small-town-like atmosphere of the inner streets - continued to characterize the Inner $7^{\text {th }}$ District in the interwar period as well (Figure 2).

In fact, the Jewish population of the $6^{\text {th }}$ and $7^{\text {th }}$ Districts contributed greatly to the emergence of modern popular culture in Hungary. From the end of the $19^{\text {th }}$ century onwards, Jewish people in Budapest were in general playing an active role in sports, modern journalism, café life, and all forms of show business (Zeke, 1995). Jews were heavily overrepresented among the owners of coffeehouses, cabarets, private theatres and cinemas; so were they among journalists, actors, actresses and directors of the early twentieth century. They were significant not only as producers but also consumers of entertainment; the petite bourgeoisie of Teréz- and Erzsébetváros, as well as the Budapest Jewish middle classes in general, provided a fostering environment to modern forms of popular culture as its main - though not the only - audience (Zeke, 1995; Molnár Gál, 1995; Konrád, 2013; Gluck 2008 and 2013).

In sum, the district used to represent a uniquely complex urban subculture in the first half of the $20^{\text {th }}$ century, characterized by a peculiar mixture of ethnic groups and religious denominations. The area, the inner streets in particular, had a characteristically lower middle class profile, with the predominance of small business, especially fashion trades (Szívós, 2012a, 179 and 192-193). The versatile cultural economy of the district in many ways grew out of the area's distinct social milieu, and, while its Jewish component remained strong until the late 1930s, that cultural industry also fostered a fruitful Jewish-Gentile exchange.

From the late 1930s on, however, that local milieu of the Inner $7^{\text {th }}$ District and its traditions of cross-cultural coexistence came to be increasingly threatened by the political climate of the day. Anti-Semitism was increasingly adopted as part of governmental policies in Hungary, and became more and more acceptable in parliamentary discourse. 


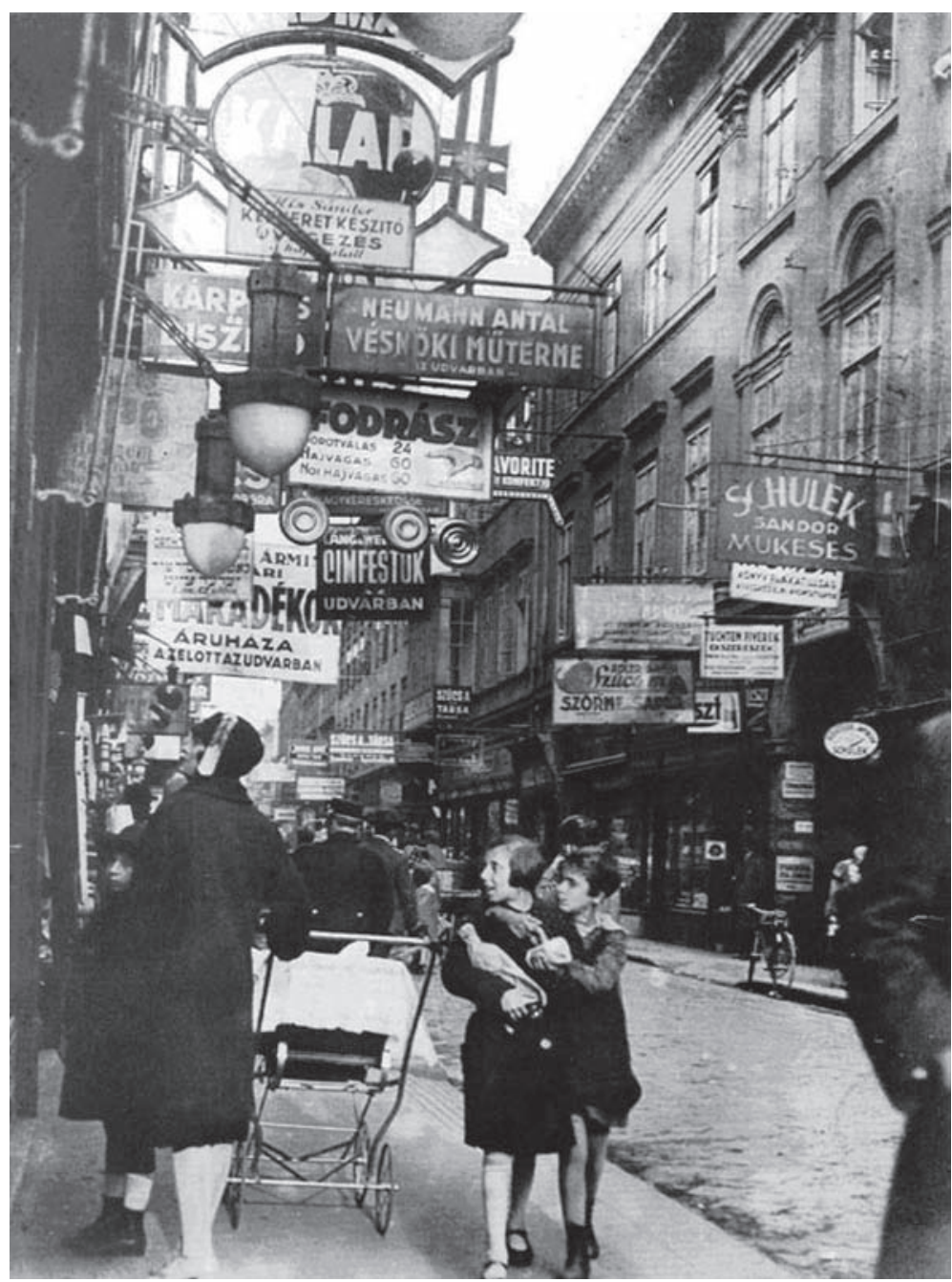

Figure 2. Király Street in 1929

After 1933, Hungary followed an increasingly pro-German orientation in its foreign policy. In the peace treaty of Trianon, signed in 1920, Hungary had been reduced to one-third of its former territory. During the interwar years, Hungarian political circles constantly sought the possibilities of the peace treaty's revision, and found a natural ally in Germany when Hitler came to power in 1933.The German orientation, however, meant increasingly explicit anti-Semitism in Hungary's public life. Discriminative measures were adopted from 1938 on in the form of the so-called anti-Jewish laws, which were modelled largely on discriminative 
legislation introduced in Nazi Germany a few years earlier. (For the full texts of the so-called anti-Jewish laws, namely Act XV of 1938, Act IV of 1939, Act XV of 1941, and Act XV of 1942, see Ezer év törvényei [Laws of one thousand years], http://www.1000ev.hu/index.php?a=1\&k=5, 1918-1945.)

The anti-Jewish laws of 1938, 1939, and 1941 had serious consequences for the residents of the inner $7^{\text {th }}$ District of Budapest, many of whom were Jewish either by religion, or by origin, or both. These laws strongly determined the atmosphere of the late 1930s, and affected the local population economically, depriving many people of their means of living, career options, and educational opportunities. While the first anti-Jewish law, passed in 1938, classified citizens as Jewish on the basis of their religious affiliation, the second anti-Jewish law, namely Act IV of 1939, already defined the category of Jewish on racial grounds; so the latter affected several people who were not Jewish by religion but by origin. The third anti-Jewish law, passed in 1941, forbade marriages between racially defined Jews and Gentiles, and - with some exceptions - declared sexual relationship between them a criminal offence.

In the light of all this, it may be surprising that in the $7^{\text {th }}$ District Jews and Gentiles continued to live in a close and undeterred symbiosis throughout the entire interwar period and even during the first years of World War II. In a recent study (Szívós 2012a), questionnaires of the 1941 Hungarian national census recorded in the Inner $7^{\text {th }}$ District provided detailed information on local residents of the area, and shed light on the confessional intermixing in buildings and apartments of the district. (In the analysis of those sources, the term Jewish was used purely as a denominational category, as it appeared in census questionnaires; see Szívós, 2012a, 173.)

The narrower area examined in the above-quoted study was Klauzál Square (Klauzál tér), the only large square located in the Inner $7^{\text {th }}$ District. If we look at the sixteen Klauzál tér houses in 1941, it is apparent that the confessional makeup of the buildings varied to a great extent, the proportion of Jewish residents ranging from 12 to $70 \%$ per building (see Table 2, based on Budapest Főváros Levéltára [Budapest City Archives] BFL IV. 1419. j, No. 1-16 Klauzál tér). The proportions of various Christian denominations (Roman Catholic, Lutheran, Calvinist, Greek Orthodox, etc.) varied from house to house as well. But one thing is obvious: each building had a mixed, Jewish-Gentile resident community, and not only in the sense that families of different confessional backgrounds were living next door to one another.

The intermixing of religions within the individual households was just as common. One finds that, with three exceptions, 23 to 63\% of the buildings' apartments were shared by Jewish and Christian residents. (Szívós, 2012a, 176.)

Expressed in an average figure, 33\% of all the apartments on Klauzál Square had Christian and Jewish inhabitants living together. There were four main types of denominationally mixed households: Jewish families sharing their apartments 
Table 2. Residents of ten Klauzál Square buildings in 1941 by religious denomination*

\begin{tabular}{|c|c|c|c|c|c|c|c|c|c|c|}
\hline \multirow[b]{2}{*}{$\begin{array}{l}\text { House } \\
\text { number }\end{array}$} & \multicolumn{2}{|c|}{$\begin{array}{l}\text { All } 1941 \\
\text { residents } \\
\text { by building }\end{array}$} & \multicolumn{2}{|c|}{\begin{tabular}{|l} 
Jewish \\
residents
\end{tabular}} & \multicolumn{2}{|c|}{$\begin{array}{l}\text { Roman } \\
\text { Catholic } \\
\text { residents }\end{array}$} & \multicolumn{2}{|c|}{$\begin{array}{l}\text { Protestant resi- } \\
\text { dents (Calvin- } \\
\text { ists, Lutherans, } \\
\text { Baptists, } \\
\text { Unitarians) }\end{array}$} & \multicolumn{2}{|c|}{$\begin{array}{l}\text { Other denomi- } \\
\text { nations } \\
\text { (Greek } \\
\text { Catholic, } \\
\text { Greek } \\
\text { Orthodox, etc. }\end{array}$} \\
\hline & 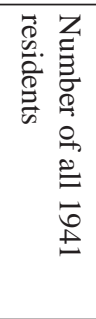 & do & 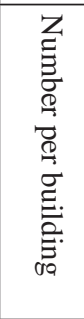 & 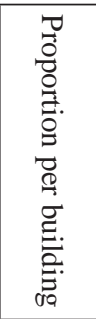 & 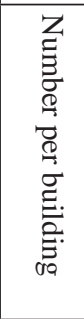 & 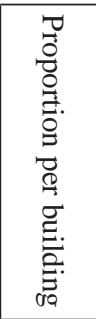 & 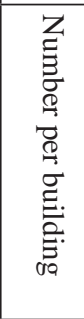 & 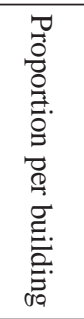 & 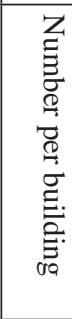 & 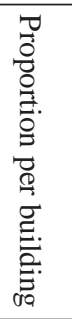 \\
\hline $\begin{array}{l}\text { Klauzál } \\
\text { Square } 1 .\end{array}$ & 47 & $100 \%$ & 27 & $57 \%$ & 17 & $36 \%$ & 2 & $4 \%$ & 1 & $2 \%$ \\
\hline $\begin{array}{l}\text { Klauzál } \\
\text { Square } 2 .\end{array}$ & 91 & $100 \%$ & 10 & $11 \%$ & 46 & $50.5 \%$ & 35 & $38 \%$ & 0 & $0 \%$ \\
\hline $\begin{array}{l}\text { Klauzál } \\
\text { Square } 3 .\end{array}$ & 82 & $100 \%$ & 44 & $54 \%$ & 30 & $37 \%$ & 5 & $6 \%$ & 0 & $0 \%$ \\
\hline $\begin{array}{l}\text { Klauzál } \\
\text { Square } 4 .\end{array}$ & 73 & $100 \%$ & 26 & $36 \%$ & 25 & $34 \%$ & 19 & $26 \%$ & 3 & $4 \%$ \\
\hline $\begin{array}{l}\text { Klauzál } \\
\text { Square } 5 .\end{array}$ & 136 & $100 \%$ & 74 & $54 \%$ & 42 & $31 \%$ & 19 & $14 \%$ & 1 & $1 \%$ \\
\hline $\begin{array}{l}\text { Klauzál } \\
\text { Square } 6 .\end{array}$ & 97 & $100 \%$ & 68 & $70 \%$ & 23 & $24 \%$ & 5 & $5 \%$ & 1 & $1 \%$ \\
\hline $\begin{array}{l}\text { Klauzál } \\
\text { Square } 7 .\end{array}$ & 56 & $100 \%$ & 16 & $28.5 \%$ & 30 & $54 \%$ & 10 & $18 \%$ & 0 & $0 \%$ \\
\hline $\begin{array}{l}\text { Klauzál } \\
\text { Square } 14 .\end{array}$ & 83 & $100 \%$ & 10 & $12 \%$ & 59 & $71 \%$ & 11 & $13 \%$ & 3 & $4 \%$ \\
\hline $\begin{array}{l}\text { Klauzál } \\
\text { Square } 15 .\end{array}$ & 166 & $100 \%$ & 98 & $59 \%$ & 45 & $27 \%$ & 19 & $11 \%$ & 4 & $2 \%$ \\
\hline $\begin{array}{l}\text { Klauzál } \\
\text { Square } 16 .\end{array}$ & 157 & $100 \%$ & 101 & $64 \%$ & 44 & $28 \%$ & 12 & $8 \%$ & 0 & $0 \%$ \\
\hline
\end{tabular}

* Without those rented spaces that functioned exclusively as stores and workshops. In this table, only those ten buildings are featured the resident populations of which could be systematically compared to the resident populations of the same buildings in 1945. 
with Christian housemaids and au-pairs; Jewish tenants subletting some of their rooms to Christian subtenants, or vice versa; apartment-workshops in which craftsmen and -women employed and also provided accommodation for apprentices of another confession; mixed-marriage households and other family types in which some of the family members were confessionally Jewish, while the others belonged to Christian denominations. (Szívós, 2012, 176-181)

The fact that Jewish and Christian individuals were living together in such close symbiosis in private spaces is in fact rather surprising if we consider the political conditions of the discussed period, and imagine the atmosphere created by the anti-Jewish laws by 1941. The cultural and psychological roots of such forms of symbiosis may have had several different components, as was analyzed in detail in Szívós, 2012, 182-186. For constraints of space, let it suffice in the present context to emphasize the subcultural uniqueness of that situation, rather untypical for Hungary and for Budapest as a whole, but very characteristic of the Inner $7^{\text {th }}$ District, where forms of intermixing had long been the norm; where Jews and Gentiles had been accustomed to each other's presence in the world of work, in public spaces, and in social relations; and where therefore anti-Semitism apparently was much less of an issue than in other social milieus of Budapest at the time.

\section{The Impact of World War II and the Holocaust: The Torn Fabric of Local Society}

Although the symbiotic relationship of ethnic groups and denominations largely prevailed during the time of the anti-Jewish laws, local patterns of coexistence were made increasingly difficult to maintain during the years of World War II.

The Inner $7^{\text {th }}$ District's population was heavily affected by wartime events and the Holocaust. Until the time of systematic air raids against Budapest, the impact of the war was less direct, and was experienced primarily by those families from which adult men were conscripted for army service or, in the case of Jewish men, were called up for labor service (for the wartime system of labor service in Hungary, see Braham, 1995). The military occupation of Hungary by German troops in March 1944, however, represented a turning point, and brought about dramatic changes.

After the German occupation of Hungary, the situation deteriorated dramatically, particularly for Hungary's Jewish population. The ghettoization and organized deportation of Hungary's Jewish population began in the countryside in May 1944, and - with the exception of Budapest - had been completed by the beginning of July that year .

In Budapest, the ghettoization of the Jewish population in June 1944 followed an untypical pattern at first. Instead of declaring one particular area of 
the city to be the Jewish ghetto, a mayoral decree ordered that all Jews in Budapest must move into so-called yellow-star houses (buildings designated specifically as obligatory Jewish places of residence). The majority of yellow-star buildings were located on the Pest side of the city, and their concentration was particularly high in the areas where the proportion of the Jewish population of Budapest had been traditionally concentrated, namely in the $5^{\text {th }}, 6^{\text {th }}$, and $7^{\text {th }}$ Districts (Cole, 2003, 105-115). As it follows from that spatial logic, the Inner $7^{\text {th }}$, and also the Inner 6th Districts were densely spotted with those buildings of forced Jewish residence (see map at http://www.csillagishazak.hu/, last accessed May 16, 2015.)

Local traditions of coexistence, however, prevailed even in those times of extreme hardship: several Gentiles chose to stay in yellow-star houses in the $7^{\text {th }}$ District (as a concession to the non-Jewish population, Gentiles were eventually allowed to stay in their old buildings if they wished, even if their buildings were declared yellow-star houses). Gentiles' persistence is indicated by the fact that 144 out of the 162 yellow-star houses in the Inner $7^{\text {th }}$ District were inhabited by mixed communities of Jews and non-Jews throughout the following five months (Braham, 1988, 218; Cole, 2003, 154).

The concentration of everyone legally classified as Jewish into yellow-star houses was obviously meant to be a prelude to the mass deportation of the Jewish population of Budapest. As a result of various pressures, however, Admiral Miklós Horthy halted the deportations in July 1944, and the Jewish population of Budapest thus avoided total extermination. The enthusiasm of survival, however, turned out to be premature. Safety was only temporary; further sufferings were awaiting Jewish residents after mid-October 1944.

On 15 October, 1944, except half a year after the German occupation, there was a coup d'état in Hungary, led by the extreme right wing Arrow Cross Party and its leader Ferenc Szálasi. The coup brought into power a radically anti-Semitic Nazi puppet regime, completely subservient to the German military command. Soon after the coup, two ghettos were organized in Budapest; the larger one was established in the Inner $7^{\text {th }}$ District, surrounded by walls, and crowds were deported, most of them on foot, as forced laborers to German or German-occupied areas (Szekeres, 1997, 91-92.)

Instead of the yellow-star houses scattered all over the city, the remaining Jewish population of Budapest was required to move into the two ghettos, except for those Jewish men between age 16 and 60, and women between age 16 and 40 who were called up for forced labor service. The ultimate intention is most likely to have been the extermination of the ghettos' population, just like it happened in several other countries. Conditions in the buildings of the "big ghetto" (i.e. the larger ghetto organized in the Inner $7^{\text {th }}$ District) were extremely crowded; by January 1945, over 70,000 people were forced to live in this relatively small 
area (Braham, 1988, 220-221; Szekeres, 1997, 93; Varga 2014: 276.) and a large number of people died in the subsequent months of diseases, malnutrition, or were killed in the raids of Arrow Cross groups.

Non-Jewish residents of the Inner $7^{\text {th }}$ District were reluctant to leave their neighborhood even in the final phase of ghettoization, that is, at the time of setting up of the walled-in Pest ghetto in late November 1944 (Cole, 2003, 375, quoting Lévai, 1948, 375); but they were eventually forced to leave the area in early December, and many of them never returned to their original residence.

Budapest was liberated by the Soviet Red Army in February 1945. The Pest side, including the ghetto in the Inner $7^{\text {th }}$ District, had been liberated on January 18 already. Human losses were immense, but the number of victims was difficult to determine (Lévai, 2014 [1946], 276). In any case, the majority of the ghetto's population eventually survived the war. The casualties as well as the survivors of the ghetto included several people who had originally not been residents of the Inner $7^{\text {th }}$ District; a massive population movement in and out of the area thus began soon after the fighting had ended. Once the non-local captives of the ghetto moved out of the area and returned to their domiciles elsewhere in Budapest, many of the non-Jewish residents began to move back to their original apartments into the former ghetto, but - as it will be demonstrated below - the majority of the area's former Gentile residents turned out to be gone once and forever.

In the spring of 1945, a new preliminary census was organized in Budapest in order to assess the war damages and the losses in human lives. As far as the Inner $7^{\text {th }}$ District is concerned, the records of the census reflect an immense transformation of local society. Here again, the sources related to the already familiar spot, namely Klauzál Square, might be illuminative. Detailed information on all residents was available for 10 buildings (out of the altogether 16 buildings surrounding Klauzál Square), so the comparison of full resident communities of 1941 with those of 1945 involved 10 buildings on the spot (BFL IV. 1419. n. „Az 1945. évi népösszeírás lakásívei és házigyüjtőívei [forms of the 1945 national census by apartments and lists of main tenants by buildings]”, Budapest, Klauzál tér, buildings No. 1-16.)

Compared to the population of 1941, only an average of $16.9 \%$ of the original residents could be found in those ten buildings of Klauzál Square in March 1945 (Table 3 and Chart 1). In that figure were included those people who were living in the same building but not in the same apartment as in 1941 (e.g. because their original apartments had been damaged). Within the average, however, there were big differences among the individual buildings. The rate of returnees - and/or residents continuously present from 1941 to March 1945 - seem to have been the highest in the case of those buildings which had been designated as yellow-star houses in June 1944. In such buildings, the rate of those 1941 Jewish residents 
(Jewish again understood in the sense of religious denomination) who survived or returned and were found by the 1945 census at their old addresses could be as high as $34 \%$.

The explanation is relatively simple: several Jewish residents living on Klauzál Square had the "privilege" of being able to stay in their old apartments all the way through 1944 and early 1945, in both phases of ghettoization: first, in June 1944, because their apartments happened to be in buildings designated as yellow-star houses, and then in late November, 1944, when their homes again happened to be located in the ghetto area that was demarcated as a zone of compulsory residence for Jews. True, from late November 1944 to mid-January 1945 those locals were forced to share their apartments with sometimes up to 14 new ghetto dwellers, but at least - if they survived the conditions at all - they had the meager consolation of being able to live through the whole infernal period of the ghetto in their own homes.

In terms of the rate of returnees, the big differences among religious denominations are quite striking. If we assess the proportion of returned residents by confession, we will find that, as a rule, the 1941 Jewish residents are present in much higher proportions in 1945 than their one-time Christian neighbors. If we count those ten buildings together for which individual questionnaires by apartment are available from 1945, we can see that on average - in rounded figures $-21 \%$ of the 1941 Jewish residents could be found in the same buildings in 1945we can see that on average $22.6 \%$ of the1941 Jewish residents could be found in the same buildings in 1945, while only $14.9 \%$ of the 1941 Roman Catholics, $4.4 \%$ of Protestants - Lutherans, Calvinists, and Baptists -, and 0\% of Greek Catholics and Greek Orthodox returned by March 1945.

(Table 3 and Chart 1). It seems that the war and especially the ghettoization policies of 1944/1945 disrupted the continuity of the one-time Christian population much more than the continuity of Jewish families’ presence.

The rest of the apartments on Klauzál Square, the residents of which had not returned, were either damaged and empty on March 1945, or were occupied by newcomers. The large number of empty apartments left behind after the liberation of the ghetto attracted hundreds of people looking for places to live: at the time of the March 1945 census, about 75 per cent of the apartments on Klauzál tér had new residents who moved in some time after January 18, 1945.

There is reason to suppose that rate of returnees increased to some extent by the end of 1945 and even beyond, as some people returned belatedly from concentration camps, DP camps, or as former prisoners of war. POWs captured by Soviet troops in 1942-45 (including unarmed labor servicemen who were in many cases captured together with Hungarian soldiers), and also civilians who were gathered in the streets of Budapest and carried away to the Soviet Union after the siege of Budapest to do forced labor in the GULAGs would often come back only years later, sometimes as late as six or seven years after the war. Oral history interviewees 


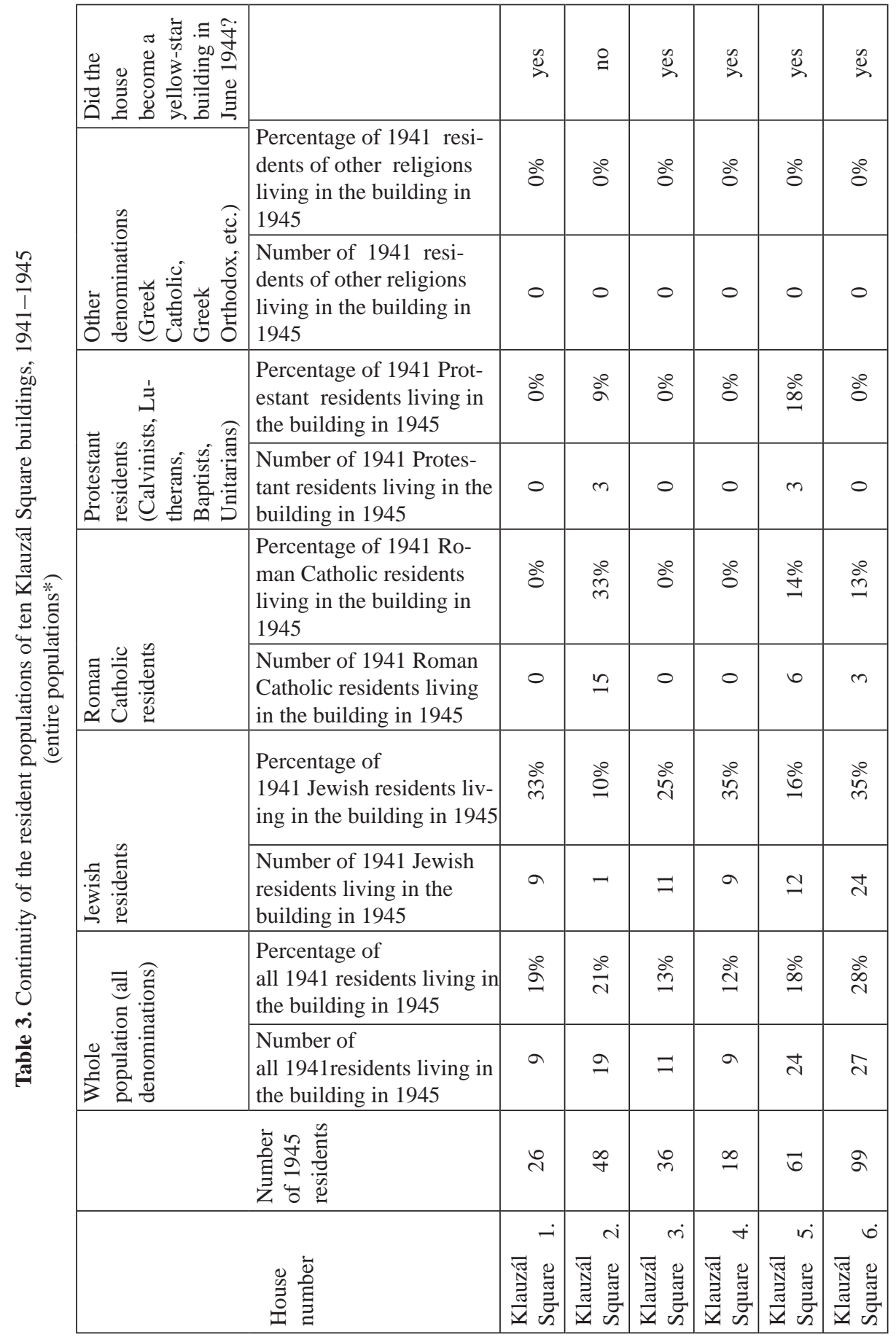




\begin{tabular}{|c|c|c|c|c|}
\hline ̊ & ๑ & 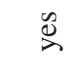 & $\stackrel{\mathscr{D}}{\check{d}}$ & \\
\hline ठे & ठ̊ & ठ̊ & ठे & 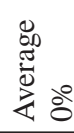 \\
\hline 0 & 0 & 0 & 0 & \\
\hline ठ̊ & ठ̊ & ठ̊ & ठे & 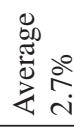 \\
\hline 0 & 0 & 0 & 0 & \\
\hline ळे & ळे & ஃ̊ & 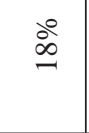 & 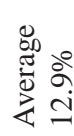 \\
\hline$\wedge$ & $\Rightarrow$ & $\nabla$ & $\infty$ & \\
\hline ळे & ठे & ㅇํㄱ & 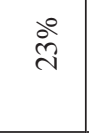 & 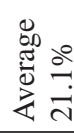 \\
\hline$m$ & 0 & $\stackrel{2}{\sim}$ & $\mathscr{N}$ & \\
\hline$\stackrel{\circ}{\circ}$ & ले & $\stackrel{\circ}{\Rightarrow}$ & $\stackrel{\text { ̊े }}{\circ}$ & 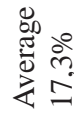 \\
\hline 으 & $\exists$ & $\stackrel{\rightarrow}{-}$ & $\vec{m}$ & \\
\hline$\stackrel{\partial}{\Rightarrow}$ & $\vec{m}$ & $\varnothing$ & 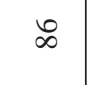 & \\
\hline 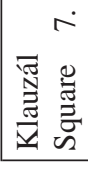 & 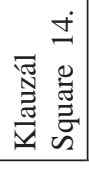 & 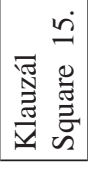 & 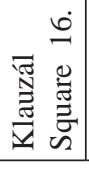 & \\
\hline
\end{tabular}


Chart 1. Percentages of 1941 residents living in ten Klauzál Square buildings at the time of the 1945 census, by denomination (rounded figures)

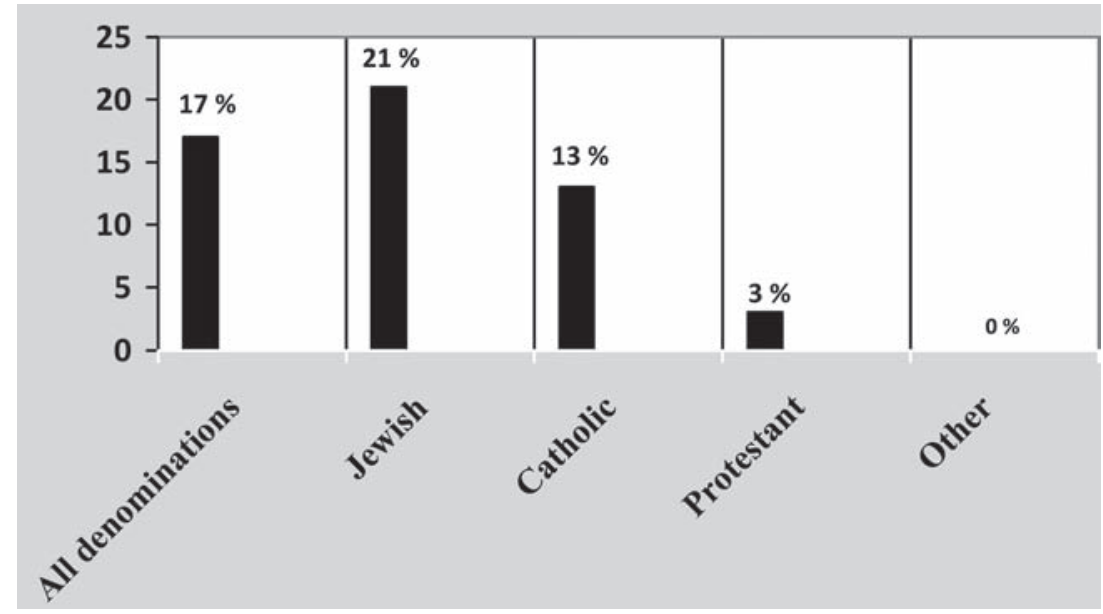

in the $7^{\text {th }}$ District do mention aquaintances or, in some cases, family members who would fall into one of the above categories of returnees. (Interview with Mrs. V. M., Febr. 1. 2011; interview with M. V., Febr. 2012; interview with Mrs. M. Z., July 5, 2011. ) But even if we assume that those late returnees altered the proportions of residential continuity and discontinuity to some degree, we cannot determine their exact impact because we have no sources from the postwar years that would offer detailed and systematic data on individual apartments and their residents, comparable to the censuses of 1941 and 1945.

As this local analysis suggests, the changes caused by the war appear to have been truly dramatic in the Inner $7^{\text {th }}$ District of Budapest. When we sum up the damage and human losses, and interpret the number of people who disappeared from the residential buildings of the former ghetto, we cannot limit our explanations to the effects the Holocaust had on local Jewish residents. We must see that in this particular neighborhood non-Jewish residents were in many ways also negatively affected by the anti-Jewish policies, notably ghettoization and forced relocation, and the formerly strong ties between Jews and Christians suffered irreparable damages during the final phase of the war.

\section{The Postwar Period}

Although the city was left in ruins by the two and a half months of the siege, life slowly went back to normal during 1945 and afterwards. But the Inner $7^{\text {th }}$ Dis- 
trict never shed memories of the ghetto, and in the postwar decades many people are said to have moved out of the area for that reason. Many Jewish survivors emigrated immediately after the war; young people who lost their relatives in the Holocaust; and those who could not forgive Hungary for what had been done to them and their families. Movements of expatriation were then stimulated by postwar political changes; the next wave started when people began to understand what the establishment of a Communist regime would really bring about for them. (On the postwar emigration of the middle and upper classes in general, see Romsics, 1999, 314-315; specifically on Jewish migration, see Erdei, 2004; Komoróczy, 2012. vol. 2, 974-975.)

Turbulent times certainly did not end with the war for the Inner $7^{\text {th }}$ District. While the years 1945-1948 brought about the partial recovery of local economy, the restoration of private business, the reorganization of religious institutions (those of the Jewish community included), and relative freedom in the field of political activity, the same years also represented a period of gradual sovietization (Romsics, 1999, 269-331). Local society was thoroughly affected by that process. The Communist regime, firmly established by 1949, almost fully eliminated private economy by nationalizing private businesses step by step, small business included (Romsics, 1999, 309; Komoróczy, 2012. Vol. 2, 925-926); it nationalized all larger residential buildings too and set out to suppress religious life, bringing the remaining confessional organizations under strict state control. In sum, the regime waged war against almost everything that used to give the Inner $7^{\text {th }}$ District a distinct character before.

The result was an exodus. Several people emigrated because their means of living and economic activities were threatened and in the end eliminated by Communist policies; or because they felt that the regime was making it impossible for them to adhere to their earlier lifestyles and freely practice their religion; or all these factors together (see e. g. Soskis, 1967, 42.) In the case of Jewish residents of the Inner $7^{\text {th }}$ District, the Palestine- and, from 1948, Israel-bound migration was organized actively by Zionist organizations - as long as the Communist regime at all allowed Zionist organizations to exist.

The emigration movement was temporarily halted when legal emigration was outlawed by Communist legislation in early 1949. But then six years later, after the outbreak of the 1956 revolution, crowds of people who missed their chance before January 1949 took the opportunity of the revolutionary upheaval to leave Hungary, many of them never to return - several residents of the $7^{\text {th }}$ District included. Oral history interviews with one-time Inner-7th-District residents often reflect a clear sense of population loss following 1956, and interviewees narrate several stories of people - including well-known local figures such as shopkeepers and entrepreneurs - who left Hungary in 1956. (In- 
terviews in Matern, 2009; interview with Mrs. Gy. V., May 2, 2014, and with G. F., May 2, 2014. ).

The successive movements of expatriation (of Jewish as well as non-Jewish Hungarians) between 1945 and 1956 had typical patterns: the main target areas were North America (both the US and Canada), Israel, and certain Central and Western European countries such as Austria, West Germany, France, and Britain. According to Viktor Karády, the patterns of Jewish migration differed by period: while until 1949 the main target was Palestine, and - after the foundation of the new state - Israel, the typical destinations of the Jewish emigrants of 1956 were North America and Western Europe (Karády, 2002, 140).

In addition to the emigrants, out-migration took place on the Budapest scale as well. A large proportion of the Inner $7^{\text {th }}$ District's population, especially the younger generations, moved out to other parts of the city during the decades of state socialism. (Ladányi, 2013, 220-221). So the societal changes that were triggered off by the war were continued by further demographic losses.

By about 1970, the early wartime families of the Inner $7^{\text {th }}$ District seem to have been largely replaced by others. As part of my research, I reconstructed the residential communities of certain buildings of the area, systematically comparing the stages of 1941, 1945, and 1970 wherever possible (census questionnaires from the 1970 census were available only for a certain number of buildings featured above in this article); and I found that in the examined buildings on average about $80 \%$ of the 1941 families and also their descendants were gone by 1970 . The Jewish families from 1941, including those still present in 1945 after the liberation, were almost all gone by 1970 (see e.g. Szívós, 2012b, 212 and 214). What is significant is that many of those "vanished" residents were not killed in the Holocaust; in spite of casualties in almost every Jewish family, a large enough number of 1941 Jewish residents were still - or again - living in their buildings after the war in 1945, as it was demonstrated above by the Klauzál Square examples. Several residents who had been registered alive in the 1945 census disappeared from the local sources afterwards, which underlines the importance of emigration and the flight from the haunting memories of the ghetto.

On the level of population statistics, unfortunately, postwar Jewish population loss in the $7^{\text {th }}$ District is difficult to assess by statistical methods, because from 1949 until 2001 (years of national censuses in Hungary) religious denomination was not recorded any more on population census questionnaires. Only less direct methods are available; for example, a comparison of the pre-1956 and post-1956 lists of taxpayers of especially the Orthodox Jewish community clearly reflect a dramatic decrease in the membership of that community. Oral history interviews, even if they do not make up for a statistical analysis, provide strong enough impressions, especially if conducted and recorded in large enough numbers. 
During the decades of state socialism, as a result of the above-described tendencies combined, the "Old Jewish Quarter" of Budapest lost much of its character as a Jewish district in terms of residential composition. The wartime losses, the postwar waves of emigration, and the massive replacement of the population by non-Jewish residents all contributed to that.

Besides the population exodus and especially the large-scale departure of observant Jewish families before 1949 and in 1956, the Jewish character of the neighborhood was on the wane also because signs of observance could no longer appear in the public space as they could before 1945. The Communist regime heavily discouraged religious practice, especially in its publicly visible forms. The cultivation of Jewish identities was equally discouraged. So Jewish community life went almost underground during the decades of state socialism, relegated largely into the private sphere; only a handful of dedicated rabbis and a shrinking number of religious institutions were holding guard to the tradition - under strict political control, and under strong pressure to cooperate with the state (Jalsovszky, Tomsics and Toronyi, 2014, 333 and 338-341.)

Many people in fact permanently left their Jewish identities behind. Jewish identities were rediscovered only in the 1980 when the regime began to develop a more tolerant attitude. A real Jewish renaissance, with a revival of religious traditions and the establishment of new communities as well as institutions, could begin in Budapest mostly after the political transition in 1990; those developments affected the Inner $7^{\text {th }}$ District as well.

The revival of collective as well as individual Jewish identity in the 1990s may have contributed to the surprising discovery of a sociological survey, conducted in 1999, about the residential distribution of Jewish people in Budapest: namely that the Jewish population was still overrepresented in the "Old Jewish Quarter" at the beginning of the new millennium, although not as much as in Újlipótváros, a middle- and upper-middle-class neighborhood (today part of the $13^{\text {th }}$ District) that has attracted high numbers of Jewish professionals and intellectuals since its formation in the interwar period (Ladányi, 2013, 221; Ladányi, 2002 in Kovács ed., 2002, 95-99). The total eclipse of the one-time "Jewish district" had been more or less public perception by then; so the sociologists were the most surprised when they came upon the above conclusion.

The 1999 survey, carried out by András Kovács, János Ladányi, Róbert Angelusz, Róbert Tardos, and Tamás Stark, adjusted its methodology to what the times dictated: in the lack of more objective criteria, various ways of self-identification were adopted as criteria of Jewishness (Kovács ed., 2002, 141-146). But in whichever way Jewishness was measured, the results of the survey shed light on a hidden and underexplored, but existing continuity of Jewish presence in the Inner $7^{\text {th }}$ District throughout the $20^{\text {th }}$ and early $21^{\text {th }}$ century. 


\section{Urban Decay and Renewal in the Postwar Period}

As far as the postwar physical development of the $7^{\text {th }}$ district is concerned, societal transformation after the Communist takeover was accompanied by a long period of physical decay, which lasted until 1989 - and even beyond. Similarly to the fate of other downtown historic districts of Budapest, the intentional neglect of the Inner $7^{\text {th }}$ District had much to do with ideological reasons, and with the regime's clear preference for concentrating on the construction of new housing estates (Lampel and Lampel, 1998; Lichtenberger, Cséfalvay and Paal, 1995).

In the 1980s, there were some attempts to revitalize the neighborhood. Urban planners and political leaders of the era had realized by then that the decades of neglect led to dramatic consequences. The decay of the building stock seemed almost irreversible. The remaining middle class, especially younger and more mobile residents, were steadily deserting the inner districts, leaving an elderly population behind. The $7^{\text {th }}$ District was among the rapidly aging areas which lost 27,700 people, that is, one quarter of its population, between 1960 and 1980. Out of that loss, 23,728 fell between 1970 és 1980 (Census publications of the Hungarian Central Statistical Bureau (KSH) digital database: http://konyvtar.ksh.hu/ neda, census of 1960, 3.e. Budapest, II; census of 1970, vol. 3.; census of 1980, 1. Budapest, 1.1., last accessed July 10, 2014.)

This was an outstanding demographic decline even among the decaying inner districts of Budapest at the time; only the $8^{\text {th }}$ District produced a comparable rate of population decrease in the same period. In both districts, the authorities themselves furthered social transformation by their housing policies. "In line with the policy of destabilizing established historic communities to reduce coherence, a large number of deprived social groups (mainly Roma) were settled by force in apartments across the [Inner $\left.7^{\text {th }}\right]$ district”, Krisztina Keresztély characterized the situation (Keresztély, 2009, 171).

The warning symptoms at some point led to the realization, on the level of state and party authorities as well, that a systematic renewal of central historic districts could not be postponed any longer.

There was a certain change in attitude as well, similarly to other countries of Europe at the time. All across Europe, the attitude toward historic neighborhoods was changing. While in the 1950s and 1960s urban reconstruction usually meant razing old housing stock to the ground and erecting new residential blocks, from the mid-1970s on milder and more considerate practices of urban renewal began to gain ground. (Lichtenberger, 1990, 29-34.) These changes had an impact on Hungary as well, in spite of the Iron Curtain still in place. While in the 1950s and 1960s the regime was openly hostile toward the historic architecture of the fin de siècle, the 1970s and 1980s saw the emergence of more respectful and considerate approaches. This was the first time when old neighborhoods began to be 
regarded as heritage, with inherent values that needed to be preserved (Egedy and Kovács, 2005, 9-20; Szívós, 2010, 384-385).

The preparation for the comprehensive revitalization of inner-city Budapest districts began in the late 1970s, and the program itself was officially announced in 1986 (Lichtenberger, Cséfalvay and Paal, 1995, 33-35). Experimental local projects of urban regeneration began in Budapest at that time; one of the testing grounds became precisely the Inner $7^{\text {th }}$ District. A large block - numbered "Block No. 15” in the citywide revitalization plans - composed of old inner-courtyard residential buildings, adjacent to Klauzál Square, was renovated, with profound changes implemented inside the block. This successful experiment produced high-quality housing with carefully preserved historic details but modernized flats and new green spaces (Lampel and Lampel, 1998, 88-104; Szívós, 2010, 391-398/2014, 44-47 and 52-53.) The physical renewal triggered off a thorough replacement of the block's former population (Hegedüs and Tosics, 1993, 85-90; Lichtenberger, Cséfalvay and Paal, 1995, 44-45).

Apart from a handful of similar projects, however, the block renewal project in the $7^{\text {th }}$ district remained an isolated example in Communist Budapest. Even though the plans were ready for the large-scale revitalization of historic districts in Budapest, the whole grand program was conceived as a state-funded enterprise, financed entirely from the sources of the national budget. This was still Communist Hungary, with a centrally planned economy, where alternative solutions to state funding were still problematic and scarce (Lichtenberger, Cséfalvay and Paal, 1995, 39-40).

The accumulating problems of state socialist economy, including the dramatic indebtedness of Hungary by that time, made the generous state support of innercity revitalization projects clearly impossible. Post-Communist Budapest, with the $7^{\text {th }}$ District included, inherited a hopelessly run-down historic housing stock which bore the marks of several decades of neglect, and which represented almost insurmountable problems for the new, democratically elected municipal governments after 1990.

\section{The Inner $7^{\text {th }}$ District after 1990}

After the collapse of Communism, profound changes took place in Budapest. Democracy was restored, municipal government was re-established, and capitalist market conditions reemerged after 1990. These changes brought about new chances for the renewal of the Inner $7^{\text {th }}$ District, but at the same time produced new problems and controversial solutions as well.

These phenomena were related to the patterns of real estate privatization adopted in post-Communist Budapest as well as to the specifics of the two-tiered munici- 
pal government structure in Budapest after 1990, which gave extensive autonomy and economic independence to the individual districts. (For an accurate summary of post-Communist municipal government structure and the resulting problems of urban renewal policies in the $7^{\text {th }}$ District, see Keresztély, 2009, 172-176.)

The recent revival and rediscovery of the neighborhood has to do with both the problems and stagnation of its recent urban development and the area's turbulent past. Stagnation, surprisingly, can be a stimulant of both social transformation and the appearance of special forms of culture.

According to models and case studies of gentrification, that process may begin at deprived and neglected but centrally located zones where real estate prices are sufficiently low to attract investors (Smith, 1996; Butler, 1997; Introduction in Atkinson and Bridge, 2005) or, in the case of spontaneous gentrification, attract relatively young and enterprising pioneers - artists, bohemians, freelancers, certain types of professionals - who could not as a rule afford buying properties of their own in more expensive neighborhoods. The Inner $7^{\text {th }}$ District is mostly an example of the latter type of spontaneous gentrification (Csanádi, Csizmady and Olt, 2012), since a large-scale, systematic, municipally coordinated revitalization of the quarter has not taken place in the last two and a half decades. Before 2010, isolated developments were mostly carried out by private investors, and generated much controversy from the point of view of heritage protection; since 2010, municipally subsidized renewal projects have also been limited to certain streets (i.e. Kazinczy Street in 2012-2013) or spots (e. g. Madách Square in 2014). But even if the revitalization of the Inner $7^{\text {th }}$ District has been spot-like rather than systematic, the renewal of certain public spaces did enhance the attractiveness of the area.

Recent publications summarize the changes by contrasting the sociological profile of the Inner $7^{\text {th }}$ District around 1990 with the current situation. By the end of the state socialist period, the quarter "had become one of the most deprived and disadvantaged inner-city neighborhoods of the capital, represented by a deeply deprived social structure” (Keresztély, 2009, 171). In the population census of 1990, the deprived character was reflected by "an extremely high share of elderly and unemployed residents, and a low share of college and university graduates." Since the mid-1990s, however, the area has experienced a thoroughgoing social transformation. By the second half of the first millennial decade, "the number of people settling in the neighborhood has increased sharply. More than $40 \%$ of its present population moved in between 1990 and 2005 (Keresztély 2009, 142, quoting Csanádi et al., 2006, 80) This newly settled population is composed mostly of young people: singles or couples without children.” (Ibid.)

The influx of relatively young, educated and mobile new inhabitants can be explained partially by the real estate prices of the neighborhood which remained affordable until the mid-2010s; partially by the central location and the proximity of inner-city institutions of business, culture, and higher education; partially by 
the expectations regarding the area's anticipated improvement and the expected rise in real estate prices; and partially by the district's cultural attractions and entertainment potential.

In the recent one and a half decades, the Inner 7th District became very popular among younger Budapestians because of the large number of new bars and entertainment facilities opened in the area; the entertainment profile generates substantial tourist traffic as well. The most attractive venues of the 2000s became the so-called "ruin bars", unique to the Inner $7^{\text {th }}$ District. The first "ruin bars" represented a special solution of temporary utilization: they were opened in the inner courtyards of vacated buildings which were destined to be demolished, but which in some cases were placed under temporary heritage protection.

True, these attractions have proven to be somewhat double-edged from the point of view of residents. The noise and traffic of the "party quarter", as the Inner Seventh District has come to be called by many in recent years, is often disturbing for locals, and not just for old-timers. Younger residents, as soon as they arrive into a mature life cycle, may find the street buzz just another nuisance besides the other reasons that may motivate them to move on. The welcome signs of the neighborhood's social renewal conceal a negative tendency as well: "young people only intend to spend a few years in the area - the period when they are flexible and mobile - but they intend to leave as soon as they have children. The lack of green areas and parks, good schools and other services for families is a huge problem in the area” (Keresztély, 2009, 172).

Besides its entertainment potential, the Inner $7^{\text {th }}$ District has also developed an old-new cultural identity which is rooted in the area's historical Jewish past.

Many people can relate to this area on the basis of their identity, even if they do not live in the $7^{\text {th }}$ district themselves. The number of those Budapest residents who are of Jewish origin or of partly Jewish origin is hard to determine in the early 2000s, but is possible to roughly estimate. According to Tamás Stark’s calculations, the Jewish population of Hungary, understood in terms of origin, could be estimated around 118,000 for the year 2000 (Stark, 2002, 124). But Stark himself stated that the above figure would be much higher if it contained those born from "mixed" - i.e. Jewish-Gentile - marriages whose fathers were Jewish; and there is a further, significant contingent of people who are related to the above calculated Jewish population by family relations, i. e. marriages, partnerships, inlaw relations, etc. (Ibid.) Knowing that the overwhelming majority of Hungary's surviving Jewish population has been concentrated in Budapest since World War II (Karády, 2002, 69-70), one can assume that the majority of that 118,000 to 200,000-strong population lives in the Hungarian capital city today.

The post-Communist decades, especially the 1990s brought about a revival of religious life in Budapest, the revival of various forms of Judaism included. A significant number of people rediscovered their Jewish ties, if not in an ex- 
plicitly religious form, then in the form of a cultural identity (Kovács in Kovács ed. 2002, 36-39; Angelusz and Tardos in Kovács ed. 2002, 41-76.) The younger generations, born after 1970, are particularly open about their Jewish identities, and some of them, affiliated with Jewish cultural organizations like Marom Association or MAZSIKE (the latter short for Hungarian Jewish Cultural Association) work actively on building up a new Jewish subculture in Budapest. Several forms of urban cultural traditions have been revived, from Jewish theatre to cabaret and annual Jewish festivals (e.g. Jewish Summer Festival or Judafest). These events almost all take place in the Inner $7^{\text {th }}$ and Inner $6^{\text {th }}$ Districts, hosted by clubs, theatres and synagogues in the area (Gantner and Kovács, 2008) - or just in the street. Some, more frequently organized cultural festivals play upon the theme of local identities, joining forces of neighboring districts: one such event is Negyed6Negyed7 (Quarter6Quarter7) Festival, recently refashioned as Negyed 7Negyed 8 (Quarter7Quarter8).

Jewish memory is cultivated in other ways as well, and not only by people of Jewish origin. Besides the official commemorations at the Holocaust memorials located in the Inner $7^{\text {th }}$ District, there are civil demonstrations and acts of commemoration as well. The March of Life, organized annually, commemorates survival and the survivors of the Holocaust. In recent years it has grown into a mass march, attended also by several people who are not of Jewish origin. Participating in it has become a form of expressing solidarity; in the eyes of many, the March of Life is also a demonstration against racism and anti-Semitism, and against the toleration of these in public discourse in Hungary. In certain years, e.g. in 2011, the March of Life started in the Inner $7^{\text {th }}$ District.

\section{Summary}

The Inner $7^{\text {th }}$ District is an ideal case study for a modern urban historian examining urban transitions and the impact of political changes on urban society.

Firstly, the story of the district raises practically all the questions and problems of urban development related to the historic centers of Central European cities, from questions of $19^{\text {th }}$-century urban planning to cycles of urban decay and renewal in the $20^{\text {th }}$ and $21^{\text {st }}$ centuries.

Secondly, the Inner 7th District of Budapest is an ideal case study because it mirrors the most dramatic developments of $20^{\text {th }}$ century Hungarian history on the local scale. The neighborhood was strongly influenced by the political events of the 1930s and 1940s, and acquired central importance in the history of the Hungarian Holocaust. Reestablished as a walled-in Jewish ghetto of Budapest during World War II, the district's population was heavily affected by wartime measures. The partial survival of this population is a unique component in the history of the 
Shoah. The Jewish community of Budapest was the only large surviving Jewish population in Central Europe, the presence of which in the city is still significant. Although, as was shown in this article, several Jewish residents disappeared from the Inner $7^{\text {th }}$ district after World War II, and the area has undergone profound societal transformation during the socialist period, the Jewish component is still noticeable in its sociological makeup. Although the current social re-stratification of the district has many different roots, the revival of Jewish heritage may be identified as one of its current attractions.

\section{References}

\section{Archival sources}

Budapest Főváros Levéltára [Budapest City Archives] BFL IV. 1419. j. Az 1941. évi népszámlálás lakásívei. Budapest VII. kerület, Klauzál tér 1-16. [Individual questionnaires of the 1941 Hungarian national census by apartment, Budapest, $7^{\text {th }}$ District, 1-16 Klauzál Square].

Budapest Főváros Levéltára [Budapest City Archives] BFL IV. 1419. n. Az 1945 évi népösszeírás lakásívei. Budapest VII. kerület, Klauzál tér 1-7 and 14-16. [Individual questionnaires of the 1945 census by apartment, Budapest, $7^{\text {th }}$ District, 1-7 and 14-16 Klauzál Square].

\section{Interviews}

Interview with Mrs. V. Gy., May 2, 2014.

Interview with G. F., May 2, 2014.

Interview with Mrs. V. M., Febr. 1, 2011.

Interview with dr. M. V., Febr. 2012.

Interview with Mrs. M. Z., July 5, 2011.

All the interviews were conducted by Erika Szívós.

For further anonymous and unidentified oral history interview excerpts see also Matern 2009 below in the bibliography.

\section{Online sources}

Hungarian population censuses, 1941-1990. Központi Statisztikai Hivatal (KSH) [Hungarian Central Bureau of Statistics], Digital Database of Population Censuses (NEDA), http://konyvtar. ksh.hu/neda

Ezer év törvényei [(Hungarian) Laws of one thousand years], http://www.1000ev.hu/index. php?a=1\&k=5, 1918-1945

Open Society Archives website of yellow star buildings in Budapest in 1944, http://www.csillagoshazak.hu 


\section{Bibliography}

Atkinson, Rowland and Bridge, Gary (eds). 2005. Gentrification in a Global Context: The New Urban Colonialism. London - New York: Routledge.

Bácskai, Vera. 1995. A pesti zsidóság a 19. század első felében [The Jews of Pest in the first half of the 19th century]. Budapesti Negyed 3 (2), 5-21.

Braham, Randolph L. 1988. A magyar Holocaust [The Hungarian Holocaust] Vol. 2. Budapest - Wilmington: Gondolat - Blackburn International Corporation.

Budapest Székesföváros Statisztikai Évkönyve [Statistical Yearbook of Budapest]. 1941. Budapest: KSH

Butler, Tim. 1997. Gentrification and the Middle Classes. Aldershot, UK - Brookfield, Vt.: Ashgate, c1997.

Cole, Tim. 2003. Holocaust City: The Making of a Jewish Ghetto. New York and London: Routledge.

Csanádi, Gábor et al. 2006. Csanádi, Gábor, Csizmady, Adrienne, Kőszeghy, Lea and Tomay, Kyra: Belső-erzsébetvárosi rehabilitáció [Revitalization in the Inner Erzsébetváros/Inner 7th District]. Tér és Társadalom, 20 (1), 73-92.

Csanádi Gábor, Csizmady, Adrienne and Olt, Gergely. 2012. Átváltozóban [In transition]. Budapest: ELTE Eötvös Kiadó.

Egedy, Tamás. 2005. A városrehabilitáció néhány elméleti kérdése [Some theoretical questions of urban revitalization]. In: Tamás Egedy, ed. 2005. Városrehabilitáció és társadalom [Urban revitalization and society]. Budapest: MTA Földrajztudományi Kutatóintézet, 9-20.

Erdei, András. 2004. A magyarországi zsidóság migrációja, 1945-1955 [Migration of the Hungarian Jewish population, 1945-1955]. Beszélö, Series III, 9 (4). 69-78.

Fabó, Beáta. 1997. A moziépítészet és a város [Cinema architecture and the city]. Budapesti Negyed 6 (3), 191-230.

Fenyves, Katalin. 2010. Képzelt asszimiláció? Négy zsidó értelmiségi nemzedék önképe [Imaginary assimilation? The self-image of four Jewish intellectual generations]. Budapest: Corvina.

Frojimovics et al., 1999 = Frojimovics, Kinga, Komoróczy, Géza, Pusztai, Viktória and Strbik, Andrea. 1999. Jewish Budapest: Monuments, Rites, History. Translated from the Hungarian by Vera Szabó; translation edited by Mario Fenyő and the authors. Budapest: CEU Press.

Gantner, Brigitta Eszter and Kovács, Mátyás. 2008. Altering Alternatives: Mapping Jewish Subcultures in Budapest. In Julia Brauch, Anna Lipphardt and Alexandra Nocke, eds. 2008. Jewish Topographies: Visions of Space, Traditions of Place. Aldershot: Ashgate, 2008.

Gluck, Mary. 2004. The Budapest Flâneur: Urban Modernity, Popular Culture and the 'Jewish Question' in Fin-de-Siècle Hungary. Jewish Social Studies, 10 (3), 1-22.

Gluck, Mary. 2008. Jewish Humor and Popular Culture in Fin-de-Siècle Budapest. Austrian History Yearbook, Vol. 39, 1-21.

Gluck, Mary. 2013. The Budapest Coffee House and the Making of 'Jewish Modernity,' Journal of the History of Ideas 74 (2).

Gruber, Ruth Ellen. 2002. Virtually Jewish: Reinventing Jewish Culture in Europe. Berkeley: University of California Press.

Gruber, Ruth Ellen. 2009. Beyond Virtually Jewish: New Authenticities and Real Imaginary Spaces in Europe. Jewish Quarterly Review, 99 (4), 487-504.

Hegedüs, József and Tosics, Iván. 1993. A lakásrendszer közgazdasági és szociológiai elemzése [Economic and sociological analysis of the housing system]. Kandidátusi értekezés [Doctoral dissertation]. Budapest: Hungarian Academy of Sciences.

Jalsovszky, Katalin, Tomsics, Emőke and Toronyi, Zsuzsanna. 2014. A magyarországi zsidóság képes története [An illustrated history of Jewry in Hungary]. Budapest: Vince Kiadó.

Kalmár, János and Stalzer, Alfred. 2000. Das jüdische Wien. Wien: Pichler Verlag. Karády, Viktor. 2002. Túlélók és újrakezdök: Fejezetek a magyar zsidóság szociológiájából 1945 után [Survivors and Renewers. Chapters from the sociology of Hungarian Jewry after 1945]. Budapest: Múlt és Jövő. 
Keresztély, Krisztina. 2009. Wasting Memories - Gentrification vs. Urban Values in the Jewish Neighbourhood of Budapest. In: Monika Murzyn-Kupisz and Jacek Purchla, eds. 2009. Reclaiming Memory: Urban Regeneration in the Historic Jewish Quarters in Central Europe. Kraków: International Cultural Centre, 163-180.

Kóbor, Tamás. 2007 [1930]. Ki a gettóból. [Out of the ghetto.] Budapest: Múlt és Jövő.

Koltai, Gábor and Rácz, Attila. 2011. Ezerarcú Erzsébetváros [The thousand faces of Erzsébetváros]. Budapest: Erzsébetvárosi Önkormányzat.

Komoróczy, Géza. 2012. A zsidók története Magyarországon [The history of Jews in Hungary], Vol. 2. Pozsony/Bratislava: Kalligram, 2012.

Konrád, Miklós. 2013. Brettlik, zengerájok, orfeumok. Szórakozás és identitás a zsidó negyedben az első világháború elött [Cafés chantants and orfeums: Entertainment and identity in the Jewish Quarter of Pest before World War I]. In: Anna Perczel, ed. 2013. Ami látható, és ami láthatatlan: Az Erzsébetváros zsidó öröksége. [The visible and the invisible: the Jewish heritage of Elisabethtown, the $7^{\text {th }}$ district of Budapest]. Budapest: Erzsébetváros Polgármesteri Hivatala, 169-178.

Kőrösi, József and Thirring, Gusztáv. 1905. Budapest fơvárosa az 1901-ik évben: A népszámlálás és népleírás eredményei [The capital city Budapest in 1901: results of the census], Vol. 2. Budapest.

Kovács, András. 2002. Zsidó csoportok és identitásstratégiák a mai Magyarországon [Jewish groups and identity strategies in today’s Hungary]. In Kovács, András, ed. 2002. Zsidók a mai Magyarországon: Az 1999-ben végzett szociológiai felmérés eredményeinek elemzése [Jews in Today’s Hungary. Analysis of the results of an 1999 sociological survey]. Budapest: Múlt és Jövő.

Angelusz, Róbert and Tardos, Róbert. 2002. Társas kötelékek és kulturális tradíciók a magyar zsidóság különböző nemzedékeiben [Social ties and cultural traditions in various generations of Hungarian Jewry]. In Kovács, András, ed. 2002. Zsidók a mai Magyarországon: Az 1999-ben végzett szociológiai felmérés eredményeinek elemzése. Budapest: Múlt és Jövő. 41-76.

Kovács, András (ed.). 2002. Zsidók a mai Magyarországon: Az 1999-ben végzett szociológiai felmérés eredményeinek elemzése [Jews in today's Hungary. Anaysis of the results of an 1999 sociological survey]. Budapest: Múlt és Jövő.

Ladányi, János. 2002. A zsidó népesség térbeli elhelyezkedésének változásai Budapesten [Changes in the spatial distribution of the Budapest Jewish population]. In András Kovács, ed. 2002. Zsidóság a mai Magyarországon [Jews in today’s Hungary]. Budapest: Múlt és Jövő, 77-100.

Ladányi, János. 2008. Lakóhelyi szegregáció Budapesten [Residential segregation in Budapest]. Budapest: Új Mandátum, 2008.

Ladányi, János. 2013. Pusztulás és újjászületés a régi pesti zsidó negyedben. In A. Perczel, ed. 2013. Ami látható, és ami láthatatlan: Az Erzsébetváros zsidó öröksége. [The visible and the invisible: the Jewish heritage of Elisabethtown, the $7^{\text {th }}$ district of Budapest]. Budapest: Erzsébetváros Polgármesteri Hivatala, 217-230.

Lampel, Éva and Lampel, Miklós. 1998. Pesti bérházsors. Várospolitika, városrehabilitáció. [The fate of fin-de-siècle residential buildings in Pest: urban politics and urban revitalization]. Budapest, Argumentum.

Lévai, Jenő. 1948. Black Book on the Martyrdom of Hungarian Jewry. Zurich: The Central European Times Publishing Company.

Lévai, Jenő. 2014 [1946]. A pesti gettó csodálatos megmenekülésének hiteles története [The true history of the Pest ghetto’s miraculous rescue]. $2^{\text {nd }}$ ed. Budapest: VII. ker. Erzsébetváros Önkormányzata.

Lichtenberger, E., 1990. Stadtverfall and Stadterneuerung. Wien: Verlag der Österreichischen Akademie der Wissenschaften.

Lichtenberger, Elisabeth, Cséfalvay, Zoltán and Paal, Michaela. 1995. Várospusztulás és -felújítás Budapesten. [Urban decay and urban renewal in Budapest]. Budapest: Magyar Trendkutató Központ.

Matern, Éva. 2009. Hétköznapi legendák [Everyday legends]. In Mária Kemény ed. 2009. Kismezö, Nagymezö, Broadway. Várostörténeti tanulmányok. Ernst Múzeum: Budapest. 386-486.

Molnár Gál, Péter. 1995. A kalábriász parti. Pesti mulatságok és malacságok. Budapesti Negyed 3 (2), 73-89. 
Murzyn, Monika A. 2006. Kazimierz: The Central European Experience in Urban Regeneration. Krakow: International Cultural Centre.

Murzyn-Kupisz, Monika. 2009. Reclaiming memory or mass consumption? Dilemmas in Rediscovering Heritage in Krakow’s Kazimierz. In Murzyn-Kupisz, Monika-Purchla, Jacek (eds). Reclaiming Memory. Urban Regeneration in the Historic Jewish Quarters in Central Europe, International Cultural Centre, Kraków, 363-396.

Pařík, Arno. 2009. The Struggle to Protect the Monuments of Prague’s Jewish Town. In Murzyn-Kupisz, Monika-Purchla, Jacek (eds). 2009. Reclaiming Memory. Urban Regeneration in the Historic Jewish Quarters in Central Europe, International Cultural Centre, Kraków, 181-214.

Perczel, Olivér. 2014. Ipar és kereskedelem Erzsébetvárosban a városegyesitéstöl az I. világháború idöszakáig. [Industry and commerce in Erzsébetváros from the city unification to World War I]. Erzsébetvárosi Önkormányzat, Budapest.

Romsics, Ignác. 1999. Magyarország története a XX. században. [History of Hungary in the 20th century]. Budapest: Osiris.

Smith, Neil. 1996. The New Urban Frontier. Gentrification and the Revanchist City. London-New York: Routledge.

Soskis, Philip. 1967. The Adjustment of Hungarian Refugees in New York. International Migration Review (2) 1, 40-46. http://www.jstor.org/stable/3002606.

Stark, Tamás. 1995. A zsidóság a vészkorszakban és a felszabadulás után, 1939-1955 [(Hungarian) Jewry during the Shoah and after the liberation, 1939-1955]. Budapest, MTA TTI, 1995.

Szekeres, József. 1997. A pesti gettók 1945. januári megmentése. „A magyar Schindler” - Szalai Pál visszaemlékezései és más dokumentumok alapján. [Rescuing the Budapest ghettos in January 1945. Based on the mémoires of 'the Hungarian Schindler' Pál Szalai and other documents]. Budapest: Budapest Főváros Levéltára.

Szívós, Erika. 2010. Terhes örökség: a történelmi lakónegyedek problémája a Kádár-korszakban a Klauzál tér és környéke példáján [Burdensome heritage: the problem of historic residential districts in the Kádár Era on the example of Klauzál Square and its environs]. URBS Magyar Várostörténeti Évkönyv Vol. 5, 407-428.

Szívós, Erika. 2012a. Bonds Tried by Hard Times: Jews and Christians on Klauzál tér, Budapest, 19381945. Hungarian Historical Review 1 (1-2), 166-199. ttp://hunghist.org/index.php/83-articles/922012-1-2-szivos

Szívós, Erika. 2012b. Bérházvilág 1970-ben: Egy belső-erzsébetvárosi bérház társadalma és lakásviszonyai. Múltunk, 57 (1), 207-228.

Szücs, István dr. and Varga, Balázsné Margit. 1975. Belsö-Erzsébetváros településszociológiai vizsgálata. [An urban sociological study of Belső-Erzsébetváros/the Inner $7^{\text {th }}$ District.] Budapesti Városépítési Tervező Vállalat, Budapest.

Thirring, Gusztáv. 1935. Budapest fơváros demográfiai és társadalmi tagolódásának fejlödése az utolsó 50 évben [The demographic and social stratification of the capital city of Budapest in the past 50 years], Statisztikai Közlemények 70, Vol. 2. Budapest: Budapest Főváros Statisztikai Hivatala.

Varga, László. 2014. A magyar zsidóság útja és Lévai Jenő könyve. Utószó Lévai Jenő könyvének második kiadásához [The Path of Hungarian Jewry and Jenő Lévai’s book. Afterword to the second edition of Jenő Lévai’s book]. In Lévai, Jenő. 2014 [1946]. A pesti gettó csodálatos megmenekülésének hiteles története [The true history of the Pest ghetto's miraculous rescue]. 2nd edition. Budapest: VII. kerület Erzsébetváros Önkormányzata, 215-325.

Zeke, Gy. 1990. A budapesti zsidóság lakóhelyi szegregációja a tőkés modernizáció korszakában, 18671941 [Residential segregation of the Budapest Jewry, 1867-1941]. In Ferenc Lendvai L., Anikó Sohár and Pál Horváth (eds). 1990. Hét évtized a hazai zsidóság életében. [Seven decades in the lives of Hungarian Jews]. Budapest: MTA. 126-144.

Zeke, Gyula. 1995. A nagyvárosi kultúra új formái és a zsidóság. [New forms of metropolitan culture and the Jews]. Budapesti Negyed, 3 (2), 90-106. 